IZA DP No. 4320

Endogenous Monopsony and the Perverse Effect of the Minimum Wage in Small Firms

Leif Danziger

July 2009 


\title{
Endogenous Monopsony and the Perverse Effect of the Minimum Wage in Small Firms
}

\author{
Leif Danziger \\ Ben-Gurion University \\ and IZA
}

\section{Discussion Paper No. 4320 \\ July 2009}

IZA

P.O. Box 7240

53072 Bonn

Germany

\author{
Phone: +49-228-3894-0 \\ Fax: +49-228-3894-180 \\ E-mail: iza@iza.org
}

\begin{abstract}
Any opinions expressed here are those of the author(s) and not those of IZA. Research published in this series may include views on policy, but the institute itself takes no institutional policy positions.

The Institute for the Study of Labor (IZA) in Bonn is a local and virtual international research center and a place of communication between science, politics and business. IZA is an independent nonprofit organization supported by Deutsche Post Foundation. The center is associated with the University of Bonn and offers a stimulating research environment through its international network, workshops and conferences, data service, project support, research visits and doctoral program. IZA engages in (i) original and internationally competitive research in all fields of labor economics, (ii) development of policy concepts, and (iii) dissemination of research results and concepts to the interested public.
\end{abstract}

IZA Discussion Papers often represent preliminary work and are circulated to encourage discussion. Citation of such a paper should account for its provisional character. A revised version may be available directly from the author. 
IZA Discussion Paper No. 4320

July 2009

\section{ABSTRACT \\ Endogenous Monopsony and the Perverse Effect of the Minimum Wage in Small Firms}

The minimum wage rate has been introduced in many countries as a means of alleviating the poverty of the working poor. This paper shows, however, that an imperfectly enforced minimum wage rate causes small firms to face an upward-sloping labor supply schedule. Since this turns these firms into endogenous monopsonists, the minimum wage rate has the perverse effect of reducing employment in small firms as well as what these firms offer their workers. Thus, if there are only small firms, the minimum wage rate makes all workers that would be employed in the absence of a minimum wage rate worse off.

JEL Classification: $\quad$ J38

Keywords: endogenous monopsony, minimum wage, noncompliance, small firms

Corresponding author:

Leif Danziger

Department of Economics

Ben-Gurion University

Beer-Sheva 84105

Israel

E-mail: danziger@bgu.ac.il 


\section{Introduction}

At least since Robinson (1933), it has been recognized that under monopsony a minimum wage rate may increase both the wage rate and employment. The logic is that with an upward-sloping labor supply schedule, the marginal labor cost exceeds the wage rate and thus equals the value of the marginal product of labor at a wage rate that is below the competitive level (which is where the wage rate equals the value of the marginal product of labor). As a consequence, a minimum wage rate that is set above the monopsony wage rate effectively makes the initial part of the labor supply schedule horizontal, and may therefore reduce the marginal labor cost and increase employment.

The practical relevance of the minimum wage rate as a wonder drug for improving the lot of low-pay workers employed by monopsonists is, however, very limited today as geographic mobility has rendered the isolated company town a thing of the past. In a developed economy, the typical minimum-wage worker can be found in an urban area working in the retail trade sector where both the demand and supply side of the labor market are arguably as competitive as they can get. ${ }^{1}$

The purpose of this paper is to turn Robinson's insight on its head and show that the introduction of a minimum wage rate in a competitive labor market will lead small firms to become endogenous monopsonists to the detriment of the welfare of their workers. Specifically, we develop a model which demonstrates that a minimum wage rate will cause a small firm to face an upward-sloping labor supply schedule, and, consequently, to reduce both what it offers to employed workers and the size of its workforce. The reason is that the enforcement of the minimum wage rate is imperfect and is mostly based on inspections prompted by worker complaints. ${ }^{2}$ However, underpaid workers do often not file a complaint,

\footnotetext{
${ }^{1}$ Card and Krueger (1995), however, suggest that low-pay labor markets are monopsonistic in order to explain their empirical finding that minimum wage increases do not lead to decreases in the employment of the affected workers. See also Neumark and Wascher (1994, 2000), Dickens et al. (1999), and Card and Krueger (2000).

${ }^{2}$ In the U.S. about $84 \%$ of the compliance actions carried out in 2008 by the Employment Standards
} 
probably out of ignorance or fear of reprisal by the employer or coworkers. ${ }^{3}$ Moreover, due to the limited number of inspectors, not all complaints trigger a thorough inspection. Thus, even in the U.S. where the minimum wage rate is relatively low, noncompliance is surprisingly widespread. To illustrate, in their seminal study based on the Current Population Survey, Ashenfelter and Smith (1979) estimate that the overall compliance rate in the U.S. is only $60 \%$, and that the compliance rate for 17-19 year-old males is a mere $35 \%$. In a more recent study based on the U.S. Department of Labor survey of the apparel industry in the Los Angeles area, Weil (2005) documents that as much as $27 \%$ of all the workers are paid less than the minimum wage rate. Similarly, using a recent Current Population Survey, Cortes (2005) finds that the compliance rate is only $28 \%$ for native males and goes down to $20 \%$ for immigrant males. ${ }^{4}$

In our model, a firm that is caught paying an endogenously determined subminimum wage rate is punished by being forced to pay workers back wages and awards, and perhaps also a fine. Therefore, when deciding what to pay a worker, a firm will compare the minimum wage rate to the expected labor cost, which is the subminimum wage rate plus the probability of the firm being caught multiplied by the penalty. If the minimum wage rate does not exceed the expected labor cost, the firm will pay the minimum wage rate; otherwise it will choose to pay only the subminimum wage rate.

Since, as mentioned, most inspections of minimum wage infractions are motivated by

Administration's Wage and Hour Division (for minimum wage and overtime violations) were motivated by worker complaints (based on U.S. Department of Labor, 2008). Of course, not every complaint is justified.

3 The typical underpaid worker in the U.S. is an (illegal) immigrant or belongs to some other disadvantaged group. Furthermore, the Wage and Hour Division will not take legal action unless the worker is willing to testify in open court.

4 There is even less enforcement in developing countries, presumably due to their meager resources. Thus, $36 \%$ of workers in Trinidad and Tobago earn less than the minimum wage rate (Strobl and Walsh, 2003); $35.7 \%$ of all private sector workers in Costa Rica earn less than $95 \%$ of the minimum wage rate (Gindling and Terrell, 2005); 8.4\% of the workforce in Brazil earn less than the minimum wage rate (Neumark et al., 2006); $21 \%$ of regular workers in Indonesia are paid below the minimum wage rate (Bird and Manning, 2008); $32.4 \%$ of workers in Honduras earn less than $90 \%$ of the minimum wage rate (Gindling and Terrell, 2009); and about $40 \%$ of the population in Paraguay, Ecuador, Guyana, Nicaragua, and Columbia earn less than $95 \%$ of the minimum wage rate (Kristensen and Cunningham, 2006). 
worker complaints, the probability of detection increases with the size of a firm's workforce. Hence, even in the absence of a fine for a noncomplying firm, if the expected labor cost were to remain unchanged when the firm's workforce increases, the subminimum wage rate would have to decrease. This would cause an increase in the total pay from a noncomplying firm that is caught, with the result that the riskiness of the actual payment to each worker increases with the size of the workforce. In order to compensate the risk-averse workers for the additional risk, therefore, the expected labor cost cannot remain unchanged but must increase with the size of the firm's workforce. If a noncomplying firm is also punished by having to pay a fine, or if the workers underestimate the likelihood that they will receive back wages and awards, then this would also cause the size of the firm's workforce to have a positive effect on the expected labor cost. ${ }^{5}$

The positive relationship between the expected labor cost and the size of the firm's workforce entails that a noncompliant firm has effectively become a monopsonist. ${ }^{6}$ Thus, the larger the firm, the higher is the expected labor cost that will eventually reach the minimum wage rate. It follows then that large firms (which are the more productive firms) will comply with the minimum wage rate, while small firms (which are the less productive firms) will cheat and attempt to pay less. Empirically, for the U.S. this is supported by Weil (2005) who finds that the smaller the firm, the more likely it is to pay less than the minimum wage rate. ${ }^{7}$ The model also provides a reason for differentiating the minimum

\footnotetext{
5 Ashenfelter and Smith (1979), Grenier (1982), and Chang and Ehrlich (1985) have studied the implications of an imperfectly enforced minimum wage rate for employment, assuming that the probability of detection is independent of firm size and that the subminimum wage rate is exogenous. In Yaniv (2001) the probability of detection depends on the number of underpaid workers, and in Basu et al. (2009) the probability of detection and the subminimum wage rate are endogenous. Danziger (2009) considers the effects of an imperfectly enforced minimum wage rate on working hours and welfare.

${ }^{6}$ Search costs and informational asymmetries may also generate a positive relationship (Mortensen and Pissarides, 1994; Rebitzer and Taylor, 1995; Bhaskar et al., 2002; Flinn, 2006; and Basu et al., 2009).

7 For developing countries, Strobl and Walsh (2003) find that in Trinidad and Tobago the proportion of workers that earn less than the minimum wage rate is about four times higher in small firms than in large firms, and Gindling and Terrell $(2005,2009)$ find that in Costa Rica and Honduras the proportion of workers that earn less than the minimum wage rate is about double in small firms than in large firms.
} 
wage rate by firm size as implemented in the U.S. by Iowa, Minnesota, and West Virginia (which have state minimum wage rates that are higher for large than for small firms), and in some developing countries, e.g., Columbia, Honduras, and Panama. The minimum wage rate in many other countries, e.g., Argentina, Greece, and Ireland, depends on the sector or occupation, which could serve as a proxy for firm size.

Accordingly, our model shows that the existence of an imperfectly enforced minimum wage rate in an otherwise competitive labor market provides small firms with endogenous monopsony power, which results in the minimum wage rate having the perverse effect of reducing both the employment in small firms and the well-being of those workers that do get employed in these firms. In particular, if all the firms are small, then all the workers that would be employed in the absence of a minimum wage rate are made worse off by the minimum wage rate.

\section{The Competitive Benchmark}

In a low-pay labor market, there is a positive continuum of risk-averse workers each of whom can supply one unit of homogenous labor to a firm. Letting $w$ denote the wage rate, an employed worker's utility is $U(w)$, where $U^{\prime}(w)>0$ and $U^{\prime \prime}(w)<0$. The workers' reservation wage rates are positive, and the density of workers with the reservation wage rate $y$ is $\psi(y) \geq 0$. Hence, the aggregate labor supply is a continuous and weakly increasing function of $w$ given by $S(w) \equiv \int_{0}^{w} \psi(y) d y .^{8}$

There is also a positive continuum of risk-neutral firms. A firm's production function is $a f(n)$, where $a>0$ is the firm's idiosyncratic productivity factor, $n$ is the employment in the firm, and $f(n)$ is a common function for all firms satisfying $f(0)=0, f^{\prime}(n)>0$, $f^{\prime \prime}(n)<0$, and $f^{\prime}(0)=\infty$. The density of firms with the idiosyncratic productivity factor $a$ is $\eta(a)>0$ with support $(0, \bar{a}]$, where $\bar{a}>0$. The firms are price takers in the output

\footnotetext{
${ }^{8}$ It is only weakly increasing because $\psi(y)$ may not always be positive.
} 
market, and the price of output is fixed and equal to unity. In the absence of a minimum wage rate, a firm maximizes its profit by setting the value of the marginal product equal to the wage rate, i.e., its employment satisfies $a f^{\prime}(n)=w$. The firm's labor demand is therefore $h(w / a)$, where $h$ denotes the inverse of $f^{\prime}(n)$, and $f^{\prime \prime}(n)<0$ implies that $h^{\prime}(w / a)<0$. Thus, the aggregate labor demand is a continuous and decreasing function of $w$ given by $D(w) \equiv$ $\int_{0}^{\bar{a}} h(w / a) \eta(a) d a$.

To serve as a benchmark, we define a competitive equilibrium in the absence of a minimum wage rate:

Definition: The labor market is in a competitive equilibrium if the wage rate is such that the aggregate labor supply equals the aggregate labor demand.

We now establish:

Proposition 1: In the absence of a minimum wage rate, there exists a unique wage rate, $w^{*}$, for which the labor market is in a competitive equilibrium.

Proof: The positive reservation wage rates entail that $S(0)=0$, which assures that $S(w)<$ $D(w)$ at low wage rates, while $f^{\prime}(0)=\infty$ entails that $\lim _{w \rightarrow \infty} D(w)=0$, which assures that $S(w)>D(w)$ at high wage rates. Since $S(w)$ is continuous and weakly increasing in $w$ and $D(w)$ is continuous and decreasing in $w$, there is then a unique wage rate $w^{*}$ such that $S\left(w^{*}\right)=D\left(w^{*}\right)$.

Thus, in the absence of a minimum wage rate, there exists a unique competitive wage rate for which the aggregate labor supply is equal to the aggregate labor demand, and the labor market is in a competitive equilibrium.

\section{The Minimum Wage Rate}

We now assume that the labor market is not competitive due to the existence of a statutory minimum wage rate $m$ that exceeds the competitive wage rate. Enforcement of the minimum 
wage rate is, however, imperfect and to some extent relies on discontented workers filing a complaint with the enforcement authority. Since it is impossible to know beforehand whether any particular worker will complain, we assume only that the probability that a noncomplying firm will be inspected increases with the size of the firm's workforce (until the probability reaches one). More formally, if $\phi(n)$ denotes the probability of inspection, then $\phi(0)=0, \phi^{\prime}(n)>0$ if $\phi(n)<1$, and $\phi^{\prime}(n)=0$ if $\phi(n)=1$.

If the firm is inspected and found guilty of underpayment, i.e., $m-w>0$, then the firm will be compelled to pay its workers back wages and awards that combined equal $\beta>0$ times the underpayment. The firm may also be forced to pay a fine equal to $\kappa \geq 0$ times the underpayment. We assume that $p \equiv \beta+\kappa>1$ so that the total penalty $p(m-w)$ increases faster than the underpayment. Thus, the firm would be deterred from underpaying if detection were certain.

In order to determine whether a firm will pay workers the full minimum wage rate or only a subminimum wage rate, let $w_{n}$ denote the lowest subminimum wage rate that a firm would need to pay in order to attract $n$ workers. If the firm is inspected, it would also have to pay the penalty $p\left(m-w_{n}\right)$, so that the actual labor cost to the firm will be $w_{n}^{+} \equiv w_{n}+p\left(m-w_{n}\right)$. As the firm is risk neutral, it is concerned with the expected labor cost, which, for a firm that hires $n$ workers at the subminimum wage rate $w_{n}$, is given by

$$
\begin{aligned}
\bar{w}_{n} & \equiv[1-\phi(n)] w_{n}+\phi(n) w_{n}^{+} \\
& =[1-\phi(n) p] w_{n}+\phi(n) p m
\end{aligned}
$$

Thus, the firm will pay the minimum wage rate if the expected labor cost is at least equal to the minimum wage rate, i.e., if $[1-\phi(n) p] w_{n}+\phi(n) p m \geq m \Leftrightarrow \phi(n) p \geq 1$, which states that the likelihood that a noncomplying firm will be punished multiplied by the penalty rate $p$ is at least equal to one. On the other hand, the firm will pay a subminimum wage rate if the expected labor cost is less than the minimum wage rate, i.e., if $\phi(n) p<1$. Since $\phi(n)$ increases in $n$ (if $\phi(n)<1$ ), there exists a critical firm size $\hat{n} \equiv \phi^{-1}(1 / p)$ such that $\phi(n) p \gtreqless 1$ as $n \gtreqless \hat{n}$. Thus, firms that employ $\hat{n}$ workers are indifferent between paying the 
minimum wage rate and paying the subminimum wage rate. However, large firms, i.e., firms that employ more than $\hat{n}$ workers, will pay the minimum wage rate, while small firms, i.e., firms that employ less than $\hat{n}$ workers, will pay a subminimum wage rate.

It is apparent from its definition that the critical firm size varies inversely both with the probability that a violating firm will be inspected for a given size of its workforce and with the severity of the penalty for a firm that is caught. However, the critical firm size is independent of all the other model parameters, including the magnitude of the minimum wage rate, since paying a subminimum wage rate is always associated with an expected wage cost that exceeds the minimum wage rate if $\phi(n) p>1$, and less than the minimum wage rate if $\phi(n) p<1$. In contrast, as we shall see below, a firm's choice of whether to become large or small, as well as the actual subminimum wage rate and employment in a small firm, are also influenced by other parameters.

\section{Endogenous Monopsonists}

If a small firm that employs $n$ workers is inspected and consequently forced to pay workers back wages and awards, then a worker's total pay will be $b_{n} \equiv w_{n}+\beta\left(m-w_{n}\right)$. If there is no fine, i.e., $\kappa=0$, then $b_{n}=w_{n}^{+}$, while if the firm must also pay a fine, i.e., $\kappa>0$, then $b_{n}<w_{n}^{+}$. As workers may underestimate the probability that they will receive back wages and awards, we assume that the workers perceive that the probability is $\epsilon \phi(n)$, where $\epsilon \in[0,1] .{ }^{9}$ Hence, a worker's (perceived) expected utility from employment in a small firm with $n$ workers is $[1-\epsilon \phi(n)] U\left(w_{n}\right)+\epsilon \phi(n) U\left(b_{n}\right)$.

To determine the subminimum wage rate and the associated employment in small firms, suppose that the subminimum wage rate in a small firm is such that a worker's certaintyequivalent wage rate, denoted by $c$, is the same in all small firms regardless of their size.

\footnotetext{
9 See Hertwig (2004) et al. and Hau (2009) et al. for evidence that the probability of a rare positive event (i.e., receiving back wages and awards) is underweighted in decisions based on experience.
} 
That is, for a given $c$, the subminimum wage rate $w_{n}(c)$ satisfies $^{10}$

$$
[1-\epsilon \phi(n)] U\left[w_{n}(c)\right]+\epsilon \phi(n) U\left[b_{n}(c)\right]=U(c) \text { for all } n<\hat{n}
$$

However, small firms are concerned with the expected labor cost rather than with the certainty-equivalent wage rate or the subminimum wage rate, and the following lemma establishes that there is a monotonically increasing relationship between the expected labor cost and the size of a firm's workforce for a given certainty-equivalent wage rate:

Lemma 1: $d \bar{w}_{n}(c) / d n>0$ for a given $c$.

Proof: See the Appendix.

To understand the intuition of the lemma, suppose first that a noncomplying firm caught underpaying only has to pay back wages and awards to the workers, but no fine, and that the workers correctly discern the probability of receiving back wages and awards. Then $b_{n}=w_{n}^{+}$ and $\epsilon=1$. If a firm's expected labor cost were to remain unchanged with an increase in $n$, and hence also with an increase in the probability that the firm is inspected and forced to pay workers back wages and awards, the subminimum wage rate would have to decrease. However, a decrease in the subminimum wage rate would entail an increase in the total pay to a worker who receives back wages and awards (because $p>1$ ), so the result would be an increase in the riskiness of the workers' income. ${ }^{11}$ As workers are risk averse, the increased

10 Since the subminimum wage rate is then a function of $c$, we write $w_{n}(c), w_{n}^{+}(c), \bar{w}_{n}(c)$, and $b_{n}(c)$ from now on.

${ }^{11}$ It follows from the definition of the expected labor cost and $b_{n}(c)=w_{n}^{+}(c)$ that

$$
\begin{aligned}
w_{n}(c) & =\frac{\bar{w}_{n}(c)-\phi(n) p m}{1-\phi(n) p}, \\
b_{n}(c) & =\frac{p m[1-\phi(n)]-(p-1) \bar{w}_{n}(c)}{1-\phi(n) p} .
\end{aligned}
$$

Hence, for a given $\bar{w}_{n}$,

$$
\frac{d w_{n}(c)}{d \phi(n)}=-\frac{p\left[m-\bar{w}_{n}(c)\right]}{[1-\phi(n) p]^{2}}<0
$$


riskiness would reduce the certainty-equivalent wage rate. Hence, if the certainty-equivalent wage rate is to remain unchanged with an increase in $n$, the firm's expected labor cost must increase with $n$ in order to compensate the workers for the additional risk.

Suppose next that a noncomplying firm that is caught must also pay a fine, which drives a wedge between the firm's expected labor cost and the worker's expected wage rate. That is, $b_{n}<w_{n}^{+}$. Since a higher $n$ makes it more likely that the firm is caught and incurs the fine, the firm's expected labor cost increases faster with $n$ than the worker's expected wage rate increases with $n$. The existence of a fine, therefore, accentuates the increasing relationship between the expected labor cost and the size of a firm's workforce for a given certainty-equivalent wage rate.

Finally, suppose that the workers underestimate the probability that they will receive back wages and awards, which drives a further wedge between the firm's expected labor cost and the worker's expected wage rate. That is, $\epsilon<1$. The magnitude of the underestimation increases with $\phi(n)$ and hence $n$, and consequently also accentuates the increasing relationship between the expected labor cost and the size of a firm's workforce for a given certainty-equivalent wage rate.

The upshot of Lemma 1 is that for a given certainty-equivalent wage rate the imperfectly enforced minimum wage rate causes the expected marginal labor cost, which is given by

$$
\begin{aligned}
g(n, c) & \equiv \partial\left[n \bar{w}_{n}(c)\right] / \partial n \\
& =\bar{w}_{n}(c)+n \partial\left[\bar{w}_{n}(c)\right] / \partial n,
\end{aligned}
$$

to exceed the expected labor cost $\bar{w}_{n}(c)$. This turns the small firms into endogenous monopsonists that pay workers less than the minimum wage rate and are able to hire additional workers only by increasing the expected labor cost.

$$
\frac{d b_{n}(c)}{d \phi(n)}=\frac{p(p-1)\left[m-\bar{w}_{n}(c)\right]}{[1-\phi(n) p]^{2}}>0
$$

Since $\phi(n)$ increases with $n$, for a given $\bar{w}_{n}(c)$, an increase in $n$ leads to a decrease in $w_{n}(c)$ and to an increase in $b_{n}(c)$. Thus, a worker's income becomes riskier when $n$ increases. 


\section{The Minimum-Wage Equilibrium}

A large firm maximizes its profit by setting the value of the marginal product equal to the minimum wage rate, i.e., its employment satisfies $a f^{\prime}(n)=m$. Thus, the labor demand of a large firm with idiosyncratic productivity factor $a$ is $h(m / a)$, with the firm selecting the lucky workers from among those having reservation wage rates not exceeding the minimum wage rate. The large firm's profit is then $\pi_{a}^{\ell}(m) \equiv a f[h(m / a)]-m h(m / a)$.

For a given certainty-equivalent wage rate, a small firm maximizes its expected profit by setting the value of the marginal product equal to the expected marginal labor cost, i.e., its employment satisfies $a f^{\prime}(n)=g(n, c) .{ }^{12} \quad$ Therefore, the labor demand of a small firm, denoted by $h_{a}^{s}(c)$, is a continuous function of the certainty-equivalent wage rate as well as of the firm's idiosyncratic productivity factor. The small firm's expected profit is then $\pi_{a}^{s}(c) \equiv \operatorname{af}\left[h_{a}^{s}(c)\right]-\bar{w}_{n} h_{a}^{s}(c)$.

Each firm takes the certainty-equivalent wage rate as given in choosing whether to become a large firm that pays the minimum wage rate, or to become a small firm that pays a subminimum wage rate. On the one hand, a large firm benefits more from having a higher idiosyncratic productivity factor than does a small firm, ${ }^{13}$ while, on the other hand, a small firm benefits from the expected wage rate being less than the minimum wage rate. Hence, there exists a unique critical idiosyncratic productivity factor $\hat{a}(c)$ defined by $\pi_{\hat{a}(c)}^{\ell}(m)=$ $\pi_{\hat{a}(c)}^{s}(c)$ such that $\pi_{a}^{\ell}(m) \gtrless \pi_{a}^{s}(c)$ as $a \gtrless \hat{a}(c) .{ }^{14} \quad$ Accordingly, firms with an idiosyncratic

\footnotetext{
${ }^{12}$ It is assumed that the value of the marginal product of a small firm falls faster with employment than does the expected marginal labor cost, i.e., $\partial\left[a f^{\prime}(n)\right] / \partial n<\partial g(n, c) / \partial n$. This assumption is always satisfied if the expected marginal labor cost is nondecreasing in employment.

13 The envelope theorem implies that the derivative of a large firm's profit with respect to $a$ is $d \pi_{a}^{\ell}(m) / d a=$ $f[h(m / a)]$, and that the derivative of a small firm's expected profit with respect to $a$ is $d \pi_{a}^{s}(c) / d a=f\left[h_{a}^{s}(c)\right]$. Since $f^{\prime}(n)>0$ and $h(m / a)>\hat{n}>h_{a}^{s}(c)$, it follows that $d \pi_{a}^{\ell}(m) / d a>d \pi_{a}^{s}(c) / d a$.

14 Since $w_{\hat{n}}=m$, the critical idiosyncratic productivity factor cannot be less than $m / f^{\prime}(\hat{n})$. If $\pi_{m / f^{\prime}(\hat{n})}^{\ell}(m)=\pi_{m / f^{\prime}(\hat{n})}^{s}(c)$, and hence $\pi_{a}^{\ell}(m)>\pi_{a}^{s}(c)$ for all $a>m / f^{\prime}(\hat{n})$, then $\hat{a}(c)=m / f^{\prime}(\hat{n})$. If $\pi_{m / f^{\prime}(\hat{n})}^{\ell}(m)<\pi_{m / f^{\prime}(\hat{n})}^{s}(c)$, and hence $\pi_{a}^{\ell}(m)<\pi_{a}^{s}(c)$ for some $a>m / f^{\prime}(\hat{n})$, then $\hat{a}(c)>m / f^{\prime}(\hat{n})$. A firm's employment is a continuously increasing function of $a$ except for an upward jump in employment at $a=\hat{a}(c)$ if $\hat{a}(c)>m / f^{\prime}(n)$.
} 
productivity factor equal to $\hat{a}(c)$ are indifferent between being large and small, while firms with an idiosyncratic productivity factor exceeding $\hat{a}(c)$ will choose to be large, and firms with an idiosyncratic productivity factor less than $\hat{a}(c)$ will choose to be small. Of course, it is possible that the minimum wage rate will be so high that $\hat{a}(c)>\bar{a}$, in which case even the most productive firm will choose to be small and there will be no large firms. However, since $\eta(a)>0$ for $a \in(0, \bar{a}]$, there will always be small firms.

The aggregate labor supply to the small firms consists of the workers not employed in the large firms. The density of these workers, which depends on how the large firms select their workers, is denoted by $\psi^{s}(y)$ and satisfies $\int_{0}^{m} \psi^{s}(y) d y=\int_{0}^{m} \psi(y) d y-\int_{\hat{a}(c)}^{\bar{a}} h(m / a) \eta(a) d a$, where $\int_{\hat{a}(c)}^{\bar{a}} h(m / a) \eta(a) d a$ is the aggregate employment in the large firms (which is zero if there are no large firms). A worker is indifferent between being employed and unemployed if the certainty-equivalent wage rate is equal to his reservation wage rate, will want to be employed if the certainty-equivalent wage rate exceeds his reservation wage rate, and will want not to be employed if it is less. Hence, the aggregate labor supply to small firms is a continuous and weakly increasing function of $c$ given by $S^{s}(c) \equiv \int_{0}^{c} \psi^{s}(y) d y$.

In order to determine the aggregate labor demand of the small firms, note that if $\hat{a}(c)=m / f^{\prime}(\hat{n})$, then $\hat{a}(c)$ is independent of $c$. However, since a higher certainty-equivalent wage rate does not influence the profit of a large firm, but reduces the expected profit of a small firm, if $\hat{a}(c)>m / f^{\prime}(\hat{n})$, the critical idiosyncratic productivity factor is a continuously decreasing function of the certainty-equivalent wage rate. ${ }^{15}$ It follows that the aggregate labor demand of the small firms is a continuous function of $c$ given by

${ }^{15}$ Formally, if $\hat{a}(c)>m / f^{\prime}(\hat{n})$, differentiating $\pi_{\hat{a}(c)}^{\ell}(m)=\pi_{\hat{a}(c)}^{s}(c)$ with respect to $c$ yields

$$
\begin{aligned}
\frac{d \hat{a}(c)}{d c} & =\frac{\partial \pi_{\hat{a}(c)}^{s}(c) / \partial c}{\partial\left[\pi_{\hat{a}(c)}^{\ell}(m)-\pi_{\hat{a}(c)}^{s}(c)\right] / \partial \hat{a}(c)} \\
& =-\frac{h_{a}^{s}(c) \partial \bar{w}_{n} / \partial c}{f\{h[m / \hat{a}(c)]\}-f\left[h_{\hat{a}(c)}^{s}(c)\right]} \\
& =-\frac{h_{a}^{s}(c)[1-\phi(n) p] \partial w_{n} / \partial c}{f\{h[m / \hat{a}(c)]\}-f\left[h_{\hat{a}(c)}^{s}(c)\right]}
\end{aligned}
$$


$D^{s}(c) \equiv \int_{0}^{\hat{a}(c)} h_{a}^{s}(c) \eta(a) d a$.

We now define a minimum-wage equilibrium:

Definition: The labor market is in a minimum-wage equilibrium if the certaintyequivalent wage rate and the associated critical level of the idiosyncratic productivity factor are such that

(1) Firms whose idiosyncratic productivity factor exceeds the critical level will be large, and firms whose idiosyncratic productivity factor is less than the critical level will be small.

(2) Each large firm pays the minimum wage rate and employes the profitmaximizing workforce consisting of workers whose reservation wage rates do not exceed the minimum wage rate.

(3) The aggregate labor supply of workers not employed in the large firms equals the aggregate labor demand of the small firms.

We now establish the existence of a minimum-wage equilibrium and compare it to the competitive benchmark:

\section{Proposition 2:}

(1) There exists a certainty-equivalent wage rate, $c^{*}$, for which the labor market is in a minimum-wage equilibrium.

(2) The certainty-equivalent wage rate in the minimum-wage equilibrium is less than the competitive wage rate, that is, $c^{*}<w^{*}$.

Since eq. (1) implies that

$$
\frac{\partial w_{n}}{\partial c}=\frac{U^{\prime}(c)}{[1-\epsilon \phi(n)] U^{\prime}\left[w_{n}(c)\right]+\epsilon \phi(n)(1-\beta) U^{\prime}\left[b_{n}^{+}(c)\right]}
$$

is positive (see note 17 in the Appendix), and $h[m / \hat{a}(c)]>h_{\hat{a}(c)}^{s}(c)$ implies that $f\{h[m / \hat{a}(c)]\}-f\left[h_{\hat{a}(c)}^{s}(c)\right]$ is positive, it follows that $d \hat{a}(c) / d c<0$. 
Proof: Observe that $S^{s}(0)=0$ and $D^{s}(0)>0$ (since $f^{\prime}(0)=\infty$ implies that each small firm's labor demand is positive at $c=0$ ) assure that $S^{s}(c)<D^{s}(c)$ for low values of $c$. If there are only small firms, then their aggregate labor supply would be $S^{s}(c)=S(c)$ and their competitive aggregate labor demand would be $D(c)=\int_{0}^{\hat{a}(c)} h(c / a) \eta(a) d a$. The fact that $w^{*}$ is the competitive wage rate then entails that $S^{s}(c) \geq \int_{0}^{\hat{a}(c)} h(c / a) \eta(a) d a$ for all $c \geq w^{*}$, with the inequality being strict except at $c=w^{*}$. If there are also large firms, then these firms will hire less workers than they would at the competitive wage rate, which makes the above inequality strict also at $c=w^{*}$, i.e., $S^{s}(c)>\int_{0}^{\hat{a}(c)} h(c / a) \eta(a) d a$ for all $c \geq w^{*}$. Since the monopsony power of the small firms implies that their aggregate labor demand is lower than under competitive conditions, i.e., $D^{s}(c)<\int_{0}^{\hat{a}(c)} h(c / a) \eta(a) d a$ for $c \geq w^{*}$, it is assured that $S^{s}(c)>D^{s}(c)$ for $c \geq w^{*}$. Hence, the labor market cannot be in a minimum-wage equilibrium for any $c \geq w^{*}$. However, since $S^{s}(c)$ is continuous and weakly increasing in $c$, and $D^{s}(c)$ is continuous in $c$, there is a certainty-equivalent wage rate $c^{*}<w^{*}$ for which $S^{s}\left(c^{*}\right)=D^{s}\left(c^{*}\right)$.

Proposition 2 shows that in the minimum-wage equilibrium any large firm pays the minimum wage rate and has its labor demand satisfied. At the same time, a subminimumwage labor market arises in which a competitively determined certainty-equivalent wage rate equalizes the labor supply of the workers not employed in the large firms with the labor demand of the small firms. The equilibrium certainty-equivalent wage rate is generally not unique both because the aggregate labor demand of the small firms may not always decrease in $c$, and because the aggregate labor supply to the small firms depends on how the large firms select their workers from among those with reservation wage rates not exceeding the minimum wage rate. ${ }^{16}$ Furthermore, while the equilibrium certainty-equivalent wage rate

16 If the aggregate labor demand of the small firms always decreases in $c$, then the highest possible equilibrium certainty-equivalent wage rate is obtained if all workers hired by the large firms have reservation wage rates that are less than the equilibrium certainty-equivalent wage rate. Furthermore, the equilibrium certainty-equivalent wage rate is lower, the more of the workers hired by the large firms that have reservation wage rates exceeding the equilibrium certainty-equivalent wage rate. 
is the same for all workers employed in the small firms, their subminimum wage rates differ as they depend on the size of the firm's workforce.

Large firms hire less workers at the minimum wage rate than they would in the competitive equilibrium, and some of their workers may have reservation wage rates that exceed the competitive wage rate. If the certainty-equivalent wage rate were equal to the competitive wage rate, therefore, the labor supply of workers not employed in the large firms would at least be equal to the labor demand of the small firms. However, the monopsonistic behavior of the small firms reduces their labor demand to less than the competitive level. Hence, the certainty-equivalent wage rate in the minimum-wage equilibrium is below the competitive wage rate. This entails that some of the workers who would have been employed by the small firms in the competitive equilibrium (and cannot find employment in the large firms, if there are any, at the minimum wage rate), will not be working at all in the minimum-wage equilibrium. Thus, in sharp contradiction to its purported goal, the minimum wage rate has the perverse effect of not only reducing the employment in the small firms, but also of making those workers who do get employed in the small firms worse off.

Since the small firms always reduce their labor demand to less than the competitive level in order to exploit their monopsony power, Proposition 2 is valid whether there are both large and small firms, or only small firms. Consequently, from the fact that $c^{*}<w^{*}$ in the minimum-wage equilibrium, we have the following:

Corollary: If all firms are small, then all the workers that would be employed in the competitive equilibrium are worse off in the minimum-wage equilibrium.

Clearly, the only workers who benefit from the minimum wage rate are those who get employed in large firms. Thus, if there are no large firms, all workers who would be employed in the absence of a minimum wage rate lose from its existence. 


\section{Conclusion}

This paper has examined the consequences of introducing a minimum wage rate in an otherwise competitive low-pay labor market. Our finding is diametrically opposite to Robinson's well-known insight that under monopsony a minimum wage rate can enhance competitiveness and thereby increase both the wage rate and the employment of low-pay workers. The reason is that the minimum wage rate is not perfectly enforced which causes small firms to face an upward-sloping labor supply schedule. Specifically, we show that introducing a minimum wage rate in a competitive labor market turns small firms into endogenous monopsonists, and that the minimum wage rate therefore has the perverse effect of reducing the employment in the small firms as well as what these firms will offer their workers. Thus, if there are only small firms, the minimum wage rate makes all workers that would be employed in the absence of a minimum wage rate worse off. 


\section{Appendix}

We want to show that for a given certainty-equivalent wage rate, the expected labor cost in small firms, $\bar{w}_{n}(c)$, increases with $n$. Note that $n$ does not affect $\bar{w}_{n}(c)$ directly, but only indirectly through its effect on $\phi(n)$ and further via the effect of $\phi(n)$ on $w_{n}(c)$. Since $\phi(n)$ increases with $n$ (because $\phi(n)<1$ ), in order to show that $\bar{w}_{n}(c)$ increases with $n$, it suffices to show that $\bar{w}_{n}(c)$ increases with $\phi(n)$.

Differentiating $\bar{w}_{n}(c)$ with respect to $\phi(n)$ yields

$$
\frac{d \bar{w}_{n}(c)}{d \phi(n)}=w_{n}^{+}(c)-w_{n}(c)+[1-\phi(n) p] \frac{d w_{n}(c)}{d \phi(n)} .
$$

Using that eq. (1) implies that

$$
\frac{d w_{n}(c)}{d \phi(n)}=\frac{\epsilon\left\{U\left[w_{n}(c)\right]-U\left[b_{n}(c)\right]\right\}}{[1-\epsilon \phi(n)] U^{\prime}\left[w_{n}(c)\right]+\epsilon \phi(n)(1-\beta) U^{\prime}\left[b_{n}(c)\right]},
$$

one obtains that

$$
\frac{d \bar{w}_{n}(c)}{d \phi(n)}=w_{n}^{+}(c)-w_{n}(c)+\frac{[1-\phi(n) p] \epsilon\left\{U\left[w_{n}(c)\right]-U\left[b_{n}(c)\right]\right\}}{[1-\epsilon \phi(n)] U^{\prime}\left[w_{n}(c)\right]+\epsilon \phi(n)(1-\beta) U^{\prime}\left[b_{n}(c)\right]},
$$

which has the same sign $\operatorname{as}^{17}$

$$
A \equiv[1-\epsilon \phi(n)] U^{\prime}\left[w_{n}(c)\right]+\epsilon \phi(n)(1-\beta) U^{\prime}\left[b_{n}(c)\right]-[1-\phi(n) p] \epsilon\left\{\frac{U\left[b_{n}(c)\right]-U\left[w_{n}(c)\right]}{w_{n}^{+}(c)-w_{n}(c)}\right\} .
$$

Since the utility function is strictly concave and $w_{n}^{+}(c) \geq b_{n}(c)$, it follows that

$$
\frac{U\left[b_{n}(c)\right]-U\left[w_{n}(c)\right]}{w_{n}^{+}(c)-w_{n}(c)}<U^{\prime}\left[w_{n}(c)\right]
$$

and hence that

$$
A>[1-\epsilon \phi(n)-\epsilon+\epsilon \phi(n) p] U^{\prime}\left[w_{n}(c)\right]+\epsilon \phi(n)(1-\beta) U^{\prime}\left[b_{n}(c)\right] .
$$

Using that $p \geq \beta$ and $U^{\prime}\left[w_{n}(c)\right]>U^{\prime}\left[b_{n}(c)\right]$, we then obtain that

$$
A>(1-\epsilon) U^{\prime}\left[w_{n}(c)\right]
$$

which is nonnegative. Consequently, $d \bar{w}_{n}(c) / d \phi(n)>0$ and hence $d \bar{w}_{n}(c) / d n>0$. For a given certainty-equivalent wage rate, therefore, the expected labor cost increases with $n$.

17 Note that $[1-\epsilon \phi(n)] U^{\prime}\left[w_{n}(c)\right]+\epsilon \phi(n)(1-\beta) U^{\prime}\left[b_{n}(c)\right]$ is positive, since it can be written as $[1-$ $\epsilon \phi(n)]\left\{U^{\prime}[w(c)]-U^{\prime}\left[b_{n}(c)\right]\right\}+[1-\epsilon \phi(n) \beta] U^{\prime}\left[b_{n}(c)\right]$, where each term is positive. 


\section{References}

Ashenfelter, O., Smith, R.S., 1979. Compliance with the minimum wage law. Journal of Political Economy 87, 333-350.

Basu, A.K.; Chau, N., Kanbur, R., 2009. Turning a blind eye: Costly enforcement, credible commitment and minimum wage laws, Economic Journal (forthcoming).

Bhaskar, V.; Manning, A., To, T., 2002. Oligopsony and monopsonistic competition in labor markets. Journal of Economic Perspectives 16, 155-174.

Bird, K., Manning, C., 2008. Minimum wages and poverty in a developing country: Simulations from Indonesia's Household Survey. World Development 36, 916-933.

Card, D., Krueger, A.B., 1995. Myth and measurement: The new economics of the minimum wage. Princeton, NJ: Princeton University Press.

Card, D., Krueger, A.B., 2000. Minimum wages and employment: A case study of the fastfood industry in New Jersey and Pennsylvania: Reply. American Economic Review 90, 1397-1420.

Chang, Y-M., Ehrlich, I., 1985. On the economics of compliance with the minimum wage law. Journal of Political Economy 93, 84-91.

Cortes, K.E., 2005. Wage effects on immigrants from an increase in the minimum wage rate: An analysis by immigrant industry concentration. IZA Discussion Paper No. 1064.

Danziger, L., 2009. Noncompliance and the effects of the minimum wage on hours and welfare in competitive labor markets. Labour Economics (forthcoming).

Dickens, R., Machin, S., Manning, A., 1999. The effects of minimum wages on employment: Theory and evidence from Britain. Journal of Labor Economics 17, 1-22.

Flinn, C.J., 2006. Minimum wage effects on labor market outcomes under search, matching, and endogenous contact rates. Econometrica 74, 1013-1062.

Gindling, T.H., Terrell, K., 2005. The effect of minimum wages on actual wages in formal and informal sectors in Costa Rica. World Development 33, 1905-1921.

Gindling, T.H., Terrell, K., 2009. Minimum wages, wages and employment in various sectors 
in Honduras. Labor Economics 16, 291-303.

Grenier, G., 1982. On compliance with the minimum wage law. Journal of Political Economy 90, 184-187.

Hau, R., Pleskac, T.J., Hertwig, R., 2009. Decisions from experience without sampling error. Journal of Behavioral Decision Making (forthcoming).

Hertwig, R., Barron, G., Weber, E.U., Erev, I., 2004. Decisions from experience and the effect of rare events in risky choice. Psychological Science 15, 534-539.

Kristensen, N., Cunningham, W., 2006. Do minimum wages in Latin America and the Caribbean matter? Evidence from 19 countries. World Bank Policy Research Paper 3870.

Mortensen, D.T., Pissarides, C.A., 1994. Job creation and job destruction in the theory of unemployment. Review of Economic Studies 61, 397-415.

Neumark, D., Wascher, W., 1994. Employment effects of minimum and subminimum wages: Panel data on state minimum wage laws: Reply. Industrial and Labor Relations Review 47, 497-512.

Neumark, D., Wascher, W., 2000. Minimum wages and employment: A case study of the fast-food industry in New Jersey and Pennsylvania: Comment. American Economic Review 5, 1362-1396.

Neumark, D.; Cunningham, W., Siga, L., 2006. The effects of the minimum wage in Brazil on the distribution of family incomes: 1996-2001. Journal of Development Economics 80, 136-159.

Rebitzer, J.B., Taylor, L.J., 1995. The consequences of minimum wage laws: Some new theoretical ideas. Journal of Public Economics 56, 245-255.

Robinson, J., 1933. The economics of imperfect competition. London, MacMillan.

Strobl, E., Walsh, F., 2003. Minimum wages and compliance: The case of Trinidad and Tobago. Economic Development and Cultural Change 51, 427-450.

U.S. Department of Labor, 2007, at http://www.dol.gov/esa/whd/statistics/2008FiscalYear.htm. 
Weil, D., 2005. Public enforcement/private monitoring: Evaluating a new approach to regulating the minimum wage. Industrial and Labor Relations Review 58, 238-257.

Yaniv, G., 2001. Minimum wage noncompliance and the employment decision. Journal of Labor Economics 19, 596-603. 